\title{
Ekstrak Jinten Hitam Memperbaiki Penyempitan Jalan Nafas pada Model Mencit Asthma
}

\section{Black Seed (Nigella Sativa) Extract Prevent The Thickening of Bronchus and Increase The Circumference Of Bronchial Lumen in Asthma Model Mice}

\author{
Endang Sriwahyuni ${ }^{1}$, Faradina Risza $Q^{2}$, Anita Yuni $K^{2}$ \\ ${ }^{1}$ Laboratorium IImu Faal Fakultas Kedokteran Universitas Brawijaya Malang \\ ${ }^{2}$ Program Studi Pendidikan Dokter Fakultas Kedokteran Universitas Brawijaya Malang \\ ${ }^{3}$ Jurusan Biologi Fakultas MIPA Universitas Brawijaya Malang
}

\begin{abstract}
ABSTRAK
Remodeling jalan nafas pada asma merupakan perubahan yang bersifat ireversibel dan di tunjukkan dengan penebalan epitel. Asma merupakan kondisi hipersensitif jalan nafas yang disebabkan inflamasi dan ditunjukkan dengan penyempitan bronkus. Jinten hitam sudah digunakan untuk pengobatan asma sejak lama. Studi dilakukan untuk menguji efek jinten hitam dalam mencegah penebalan bronkus dan membuktikan efek bronkodilator dengan peningkatan lingkar lumen bronkus pada model mencit asma betina dengan eksperimental in vivo. Mencit model asma dikembangkan dengan memberikan sensitisasi allergen ovalbumin yang diberikan intraperitoneal dua kali dalam 3 minggu (haro 0 dan 14) dilakukan per inhalasi tiga kali seminggu selama 6 minggu. Ekstrak jinten hitam diberikan dalam 3 dosis $(1,2 \mathrm{~g} ; 2,4 \mathrm{~g}$ and 4,8 $\mathrm{g} / \mathrm{kgBB} /$ hari) selama 9 minggu. Hasil penelitian menunjukkan bahwa pemberian jintan hitam dapat mencegah penebalan epitel bronkus dengan dosisi efektif $2,4 \mathrm{~g} / \mathrm{Kg} \mathrm{BB} /$ hari dan meningkatkan lingkar lumen bronchial dengan dosis efektif 4,8 $\mathrm{g} / \mathrm{KgBB} /$ hari. Dapat disimpulkan pemberian ekstrak jintan mencegah penebalan epital bronkus dan meningkatkan lingkar lumen bronchial pada mencit model asma.
\end{abstract}

Kata Kunci : Asma, inflamasi, jinten hitam, lingkar lumen bronkus, penebalan epitel bronkus

\begin{abstract}
Respiratory tract remodeling in asthma is a irreversible change expressed epithelial thickening. Asthma is a hypersensitivity condition of respiratory tract triggered by inflammation, which is characterized by bronchus constriction . Black seed had been empirically well known could treat asthma since long time ago. This study was aimed to test the effect of Nigella sativa in preventing the thickening of bronchus and to prove bronchodilator effect that increase the circumference of bronchial lumen in female asthma model mice by in vivo experimental study. These model mice were obtain by sensitize them with allergenic ovalbumin given intraperitoneally twice in 3 weeks (in day 0 and day 14) and then by inhalation 3 times a week for 6 weeks. Black seed extract was given in 3 doses $(1,2 \mathrm{~g} / \mathrm{kgBW} / \mathrm{day} ; 2,4 \mathrm{~g} / \mathrm{kgBW} / \mathrm{day}$, and $4,8 \mathrm{~g} / \mathrm{kgBW} /$ day) for 9 weeks. The result of this study showed that black seed could prevent the thickening of bronchus epithelia with effective dose $2,4 \mathrm{~g} / \mathrm{Kg} \mathrm{BW} /$ day and increase the circumference of bronchial lumen with effective dose 4,8 $\mathrm{g} / \mathrm{KgBW} / \mathrm{day}$. In conclusions, black seed could prevent the thickening of bronchus epithelia and increase the circumference of bronchial lumen in asthma model mice
\end{abstract}

Keyword: Asthma, black seed, inflammation, the circumference of bronchus lumen, thickening of bronchial epithelia

Jurnal Kedokteran Brawijaya, Vol. 26, No. 1, Februari 2010; Korespondensi: Endang Sriwahyuni. Laboratorium IImu Faal Fakultas Kedokteran Universitas Brawijaya Malang, JI Veteran Malang, Tel. (0341)564117Email: doc vie@yahoo.com 


\section{PENDAHULUAN}

Sejak dua dekade terakhir prevalensi asma meningkat, baik pada anak maupun dewasa. Di negara maju, peningkatan prevalensi asma berkaitan dengan polusi udara dari industri maupun otomotif, interior rumah, gaya hidup, kebiasaan merokok, pola makanan, penggunaan susu botol dan paparan alergen dini. Diperkirakan sudah 300 juta orang di dunia menderita asma dan pada tahun 2005 paling tidak ada tambahan sekitar 100 juta pasien asma lagi. Permasalahan ini tidak hanya timbul di negara maju namun juga di negara berkembang. Di Indonesia prevalensi asma diperkirakan $2 \%$ hingga $4 \%$ atau sekitar 3 hingga 5 juta orang dan $1 \%$ diantaranya memerlukan perawatan rumah sakit karena serangan asma akut yang berat (1).

Asthma merupakan gangguan inflamasi kronik saluran napas yang berhubungan dengan peningkatan kepekaan saluran nafas (2). Kepekaan saluran nafas yang merupakan tanda khas asma, ditandai dengan adanya respon berlebihan jalan napas terhadap berbagai rangsangan, baik endogen maupun eksogen. Obstruksi jalan napas pada asma terjadi karena bronkokonstriksi, oedema mukosa dinding jalan napas, obstruksi oleh mukus, dan remodelling dinding jalan napas atau disebut juga airway remodelling (3).

Airway remodelling memiliki beberapa komponen, yaitu metaplasia permukaan epitelial disertai dengan peningkatan ketebalan epitel, hiperplasia sel goblet dan peningkatan sekresi mukus, (2) penebalan otot polos saluran nafas dan (3) angiogenesis. Hal ini menyebabkan penurunan fungsi paru yang progresif dan irreversibel. Pada keadaan asma, terjadi peningkatan jumlah sel goblet yang kemudian akan meningkatkan sekresi mukus. Pada penelitian sebelumnya dengan model tikus alergi, hiperplasia sel goblet berkontribusi terhadap terjadinya penebalan epitel saluran nafas (4).

Pengobatan asma bronkial dapat dibedakan menjadi dua, yaitu obat penghilang gejala asma (reliever) dan obat pengontrol jangka panjang (controller). Reliever adalah bronkodilator yang digunakan untuk menghilangkan gejala asma pada saat terjadi serangan asma. Obat jenis ini meliputi antikolinergik inhalasi, short acting theophylline, dan short acting 2-agonist oral. Controller adalah obat yang diberikan setiap hari untuk mencegah timbulnya asma. Obat jenis ini meliputi glukokortikosteroid (inhalasi dan sistemik), leukotriene modifier, long acting 2-agonist inhalasi yang dikombinasikan dengan glukokortikosteroid, theophylline, cromones, anti IgE, dan obat steroid lainnya. Saat ini obat controller yang paling efektif adalah glukokortikosteroid inhalasi (5). Beberapa studi menunjukkan kemampuan kortikosteroid dalam mengurangi gejala asma, memperbaiki kualitas hidup dan fungsi paru, menurunkan kepekaan saluran nafas, serta mengendalikan inflamasi saluran nafas. Kortikosteroid dapat mensupresi inflamasi melalui inhibisi ekspresi sitokin, kemokin, dan molekul adhesi yang diregulasi oleh faktor transkripsi seperti nuclear factor $k b$ (NF- $\alpha \beta)$ dan aktivator protein (Ap1) (6). Namun demikian, kortikosteroid tidak dapat menyembuhkan asma secara total dan penghentian terapi akan menimbulkan kekambuhan gejala asma (5). Hal ini menunjukkan masih dibutuhkan studi lebih lanjut untuk mendapatkan alternatif pengobatan asma yang lebih efektif dan aman.

Biji dan minyak jinten hitam telah lama digunakan sebagai terapi asma di Arab dan beberapa negara timur tengah lainnya. Nigellon sebagai salah satu kandungan aktif jinten hitam disamping polimer, karbonil, dan thymoquinon terbukti efektif mencegah asthma. Hal ini telah dilaporkan oleh El-Taher dengan memberikan minyak volatile jinten hitam secara intra trakhea pada marmut. Efek tersebut disebabkan oleh efek sentral jinten hitam (7). Studi organ terpisah menunjukkan efek relaksasi otot polos trakhea marmut setelah pemberian jinten hitam. Peningkatan relaksasi otot polos sesuai dengan kenaikan dosis jinten hitam yang digunakan (8).

Penelitian di Amerika menunjukkan bahwa pemberian thymoquinone, salah satu bahan aktif dalam ekstrak jintan hitam, dapat menginhibisi sitokin pro inflamasi, tromboksan B2 dan leukotrin B4 dengan mengalihkan jalur siklooksigenase dan 5-lipoksigenase dari metabolisme asam arakhidonat. (9). Efek anti inflamasi thymoquinone dapat menginhibisi growth factor, sehingga mengurangi remodeling khususnya penebalan sel epitel dan keliling lumen bronkus.

Abbas melakukan studi pada model tikus alergi yang diberikan jinten hitam. Pemberian jinten hitam selama 24 jam, sebelum perlakuan dengan ovalbumin dapat menurunkan jumlah eosinofil darah tepi IgG1, IgG2, IL-2 dan IL-12. Efek ini sebanding dengan pemberian deksametason (10). Penelitian lain dengan thymoquinon pada model tikus alergi menunjukkan hasil yang sama. Kadar ovalbumin spesifik IgE, IgG serum. IL-4, IL-5 dan IL-13 cairan lavage bronkhoalveolar menurun pada kelompok yang diberikan thymoquinon. $\mathrm{Hal}$ ini menunjukkan bahwa thymoquinon dapat mengurangi inflamasi saluran nafas akibat alergi melalui hambatan sitokin Th2 dan infiltrasi eosinofil (9).

Sejauh ini penelitian tentang efek jinten hitam terhadap penebalan epitel bronkus dan keliling lumen bronkus sebagai indikator penyempitan saluran nafas pada kondisi asthma masih terbatas. Penelitian ini bertujuan untuk menguji efek ekstrak jinten hitam terhadap ketebalan epitel bronkus dan keliling lumen bronkus pada model mencit asma.

\section{METODE}

Penelitian ini merupakan penelitian eksperimental sederhana dengan subyek mencit dibagi secara random menjadi lima kelompok yaitu: kontrol negatif (tanpa perlakuan), kontrol positif (dengan sensitisasi ovalbumin), kelompok dengan sensitisasi ovalbumin dan pemberian ekstrak jinten hitam masing masing dosis 1,2 g/KgBB/hari, 2,4 g/KgBB/hari, dan 4,8 $\mathrm{g} / \mathrm{KgBB} /$ hari.

Pada setiap perlakuan digunakan 4 ekor mencit dengan kriteria mencit betina, umur 6-12 minggu, sehat dan bebas penyakit, dan diet bebas ovalbumin.

Aklimatisasi bagi hewan uji dilakukan selama 7 hari di 
Laboratorium Farmakologi Fakultas Kedokteran Universitas Brawijaya Malang. Pada waktu tujuh hari ini, mencit hanya diberi makan dan minum standar laboratorium secara adlibitum.

Sensitisasi ovalbumin awal dilakukan secara intraperitoneal menyuntikkan campuran $10 \mu \mathrm{g}$ ovalbumin (OVA) + $1 \mathrm{mg} \mathrm{Al}(\mathrm{OH})_{3}$ yang dilarutkan dalam $0,5 \mathrm{cc}$ normal saline ( $\mathrm{NaCl} 0,9 \%$ ) pada hari ke-0 dan hari ke-14. Sensitisasi ulangan dilakukan secara inhalasi dengan memberikan ovalbumin (OVA) $1 \%$ dalam normal saline ( $\mathrm{NaCl} 0,9 \%)$ sebanyak $8 \mathrm{cc}$ per perlakuan dengan menggunakan nebulizer OMRON tipe NU-017 selama 20 menit dengan air flow volume dan nebulization volume pada skala 1 . Sensitisasi secara inhalasi tersebut diulang selama 6 minggu sesuai jadwal, yaitu mulai hari ke 21 sampai 60 setiap 2 hari sekali, pada waktu yang kurang lebih sama pada tiap perlakuan, yaitu antara pukul 09.00-11.00 WIB .

Pemberian ekstrak jinten hitam dilakukan setiap hari secara forced feeding dengan menggunakan spuit yang pada ujungnya ditumpulkan dengan planina dan dimasukkan melalui mulut mencit. Ekstrak jinten hitam yang diberikan sebanyak $1,2 \mathrm{~g} / \mathrm{KgBB} /$ hari pada kelompok 1, 2,4 g/kgBB/hari pada kelompok 2 dan 4,8 $\mathrm{g} / \mathrm{KgBB} /$ hari pada kelompok 3 .

Pada mencit yang telah diberi perlakuan selama 9 minggu dilakukan pengambilan organ setelah sebelumnya dilakukan anestesi hingga mencit-mencit tersebut mati dengan agen anestesi ketamin dan midazolam. Organ paru diletakkan di dalam tempat organ dan difiksasi dengan formalin $10 \%$, selanjutnya dibuat sediaan histopatologi. Untuk melihat ketebalan epitel bronkus dan ukuran keliling lumen bronkus.

Sediaan epitel bronkus mencit diamati dengan indikator ketebalan epitel bronkus dan keliling lumen bronkus menggunakan mikroskop Olympus BX51 dengan perbesaran 400x sebanyak 3 lapang pandang pada masing-masing sediaan (12). Untuk dokumentasi dilakukan pemotretan terhadap hasil pengamatan dengan kamera mikroskop Olympus DP71. Selanjutnya ketebalan epitel bronkus dari keliling lumen bronkus mencit diukur dengan menggunakan software komputer Image Pro Plus. Ketebalan epitel bronkus keliling lumen bronkus dihitung sebagai rata-rata dari 3 pengukuran pada masing-masing lapang pandang.

Data dianalisis menggunakan uji one-way ANOVA dan uji Post Hoc dengan metode Tukey. Pengaruh peningkatan dosis jinten hitam terhadap penebalan epitel bronkus mencit dan ukuran keliling lumen bronkhus diuji dengan korelasi pearson dilanjutkan dengan uji regresi.

\section{HASIL}

Gambaran histopatologi bronkus mencit pada gambar 1 menunjukkan peningkatan ketebalan epitel pada kelompok kontrol positif bila dibandingkan dengan kelompok kontrol negatif. Pada semua kelompok perlakuan didapatkan ketebalan epitel bronkus yang semakin menurun jika dibandingkan dengan kelompok kontrol positif dan tidak terlalu berbeda jika dibandingkan dengan kelompok kontrol negatif.

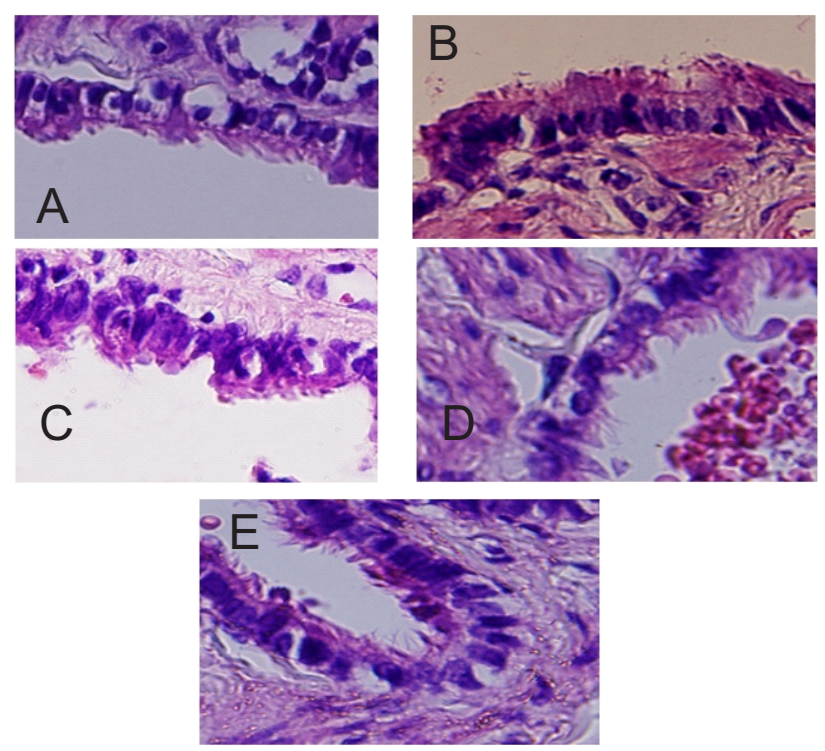

Gambar 1. Gambaran histopatologis ketebalan epitel bronkus mencit pada masing-masing kelompok perlakuan.

Keterangan:A.Kelompok kontrol negatif, B.Kelompok kontrol positif, C.Kelompok jinten hitam dosis $1,2 \mathrm{mg} / \mathrm{kgBB}$, D.Kelompok .Kelompok jinten hitam dosis $2,4 \mathrm{mg} / \mathrm{kgBB}$, E.Kelompok .Kelompok jinten hitam dosis $4,8 \mathrm{mg} / \mathrm{kgBB}$

Tabel 1 memberikan gambaran perubahan ketebalan epitel bronkus mencit pada tiap-tiap kelompok. Pada kelompok kontrol negatif hasil pengukuran epitel bronkus mencit adalah $59.9263 \mu \mathrm{m}$, sedangkan pada kelompok kontrol positif didapatkan peningkatan ketebalan epitel dengan hasil sebesar $73.7527 \mu \mathrm{m}$. Pada kelompok jinten hitam dosis $1,2 \mathrm{~g} / \mathrm{kg} \mathrm{BB}, 2,4 \mathrm{~g} / \mathrm{kgBB}$ dan $4,8 \mathrm{~g} / \mathrm{kgBB}$ terjadi peningkatan ketebalan epitel bronkus mencit yang lebih sedikit yaitu $65.1587 \mu \mathrm{m}$, $58.9580 \mu \mathrm{m}$, dan $53.5753 \mu \mathrm{m}$. Peningkatan dosis jinten hitam yang diberikan mencegah peningkatan ketebalan epitel bronkus bila dibandingkan dengan kelompok kontrol positif.

Tabel 1. Rerata ketebalan epitel bronkus mencit pada masingmasing perlakuan

\begin{tabular}{lll}
\hline Kelompok perlakuan & $\begin{array}{l}\text { Rerata ketebalan } \\
\text { epitel bronkus } \\
\mathbf{X} \pm \text { SD }(\boldsymbol{\mu m})\end{array}$ \\
\hline Kontrol (-) & $59.9263 \quad \pm 4.0826$ \\
Kontrol (+) & $73.7527 \quad \pm 5.6134$ \\
Jinten Hitam dosis $1,2 \mathrm{~g} / \mathrm{kgBB}$ & $65.1587 \quad \pm 5.9667$ \\
Jinten Hitam dosis $2,4 \mathrm{~g} / \mathrm{kgBB}$ & $58.9580 \quad \pm 7.5179$ \\
JH dosis $4,8 \mathrm{~g} / \mathrm{kgBB}$ & $53.5753 \quad \pm 3.8915$ \\
\hline
\end{tabular}

Pada uji ANOVA terdapat minimal 2 kelompok yang memiliki perbedaan ketebalan epitel bronkus mencit secara bermakna $p<0,05$. Selanjutnya dilakukan uji analisis Post Hoc dengan metode Tukey. Hasil analisis 
Post Hoc dengan metode Tukey, didapatkan bahwa antara kelompok kontrol negatif dan kontrol positif terdapat peningkatan ketebalan epitel bronkus mencit yang signifikan $(p<0,001)$. Sementara itu, pada semua kelompok perlakuan didapatkan penurunan ketebalan epitel bronkus yang signifikan bila dibandingkan dengan kontrol positif serta tidak ada perbedaan yang signifikan antara kelompok perlakuan dosis $4,8 \mathrm{~g} / \mathrm{kgBB}$ dan kelompok kontrol negatif $(p=0,054)$. Untuk mencari korelasi antara ketebalan epitel dengan pemberian ekstrak jinten hitam, dilakukan uji korelasi Pearson (bivariate-two tailed). Hasil pada correlations didapatkan nilai significancy adalah 0.000. Nilai korelasi Pearson yang didapat yaitu $r=-0.637$ menunjukkan bahwa semakin besar dosis ekstrak jinten hitam yang diberikan maka ketebalan epitel bronkus mencit akan semakin menurun dengan kekuatan korelasi kuat.

Untuk mengetahui seberapa besar pengaruh peningkatan dosis ekstrak jinten hitam terhadap ketebalan epitel bronkus mencit dilakukan uji regresi. Hasilnya, didapatkan $r$ square $=0,405$, hal ini menunjukkan bahwa pengaruh peningkatan dosis jinten hitam terhadap ketebalan epitel bronkus mencit yang dipapar allergen secara kronis adalah sebesar 40,5\%. Artinya pengaruh peningkatan dosis ekstrak jinten hitam terhadap ketebalan epitel bronkus model mencit asma tidak terlalu besar, sedangkan 59,5\% kemungkinan dipengaruhi oleh faktor lain.

Hasil pengukuran ukuran keliling lumen bronkus mencit pada kelompok kontrol dan perlakuan digambarkan pada Gambar 2.

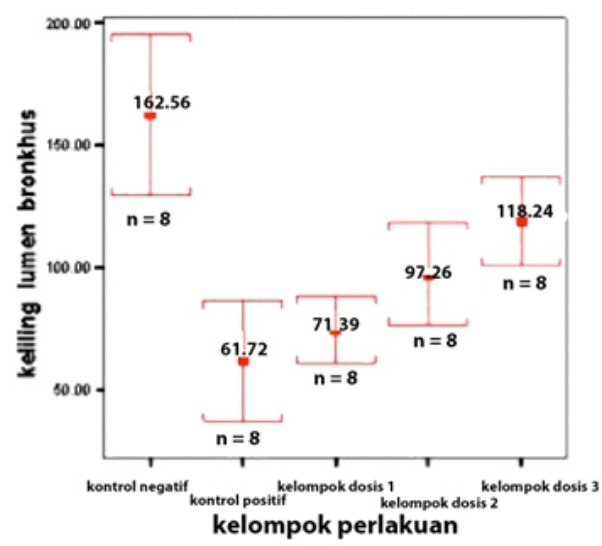

Gambar 2. Rerata keliling lumen bronkus

Pada uji ANOVA terdapat minimal 2 kelompok yang memiliki perbedaan keliling lumen bronkus mencit secara bermakna, $p<0,05$. Selanjutnya dilakukan uji analisis Post Hoc dengan metode Tukey. Hasil analisis Post Hoc Tukey, kelompok kontrol positif mempunyai keliling lumen bronkus yang lebih rendah dan berbeda bermakna dibandingkan dengan kelompok kontrol negatif, dan dosis $4,8 \mathrm{mg} / \mathrm{kg} \mathrm{BB}$, tetapi tidak berbeda bermakna dibandingkan dengan kelompok dosis 1,2 g/ $\mathrm{kgBB}$ dan dosis $2,4 \mathrm{~g} / \mathrm{KgBB}$. Kelompok dosis 4,8 g/kgBB mempunyai keliling lumen bronkus yang paling tinggi namun masih berbeda bermakna jika dibandingkan dengan kelompok kontrol negatif.

Kemudian, data dianalisa dengan menggunakan uji korelasi pearson. Dari uji Pearson didapatkan nilai signifikansi $<0,05$ (yaitu 0,000), dan koefisien korelasi $+0,919$ menunjukkan bahwa semakin tinggi konsentrasi ekstrak jinten hitam yang diberikan, maka keliling lumen bronkhus semakin bertambah dengan kekuatan korelasi yang kuat. Lalu, dilanjutkan dengan uji regresi. Dalam uji regresi tersebut, didapatkan nilai $R$ square 0,845 yang bermakna bahwa persentase pengaruh pemberian ekstrak jinten hitam terhadap keliling lumen bronkhus adalah $84,5 \%$, sedangkan $15,5 \%$ dipengaruhi variabel perancu.

\section{DISKUSI}

Hasil penelitian menunjukkan, baik secara kualitatif maupun kuantitatif, terjadi peningkatan ketebalan epitel bronkus dan penurunan keliling lumen bronkus pada mencit dengan sensitisasi ovalbumin (kontrol positif) bila dibandingkan dengan mencit tanpa sensitisasi ovalbumin. Penebalan epitel dan penyempitan lumen bronkus merupakan salah satu manifestasi dari remodeling saluran nafas yang terjadi pada keadaan saluran nafas yang tersensitisasi, misalnya pada asma bronkial. Pemberian ovalbumin pada kontrol (+) akan merangsang sel-sel dendritik untuk memproduksi sel Th2 yang akan merangsang produksi IgE. Selain itu sel Th2 juga akan merangsang keluarnya sel-sel inflamasi diantaranya sel mast, basofil, eosinofil, dan makrofag. Sel-sel inflamasi ini akan menyebabkan pelepasan mediator-mediator inflamasi, diantaranya histamin, bradikinin, leukotrien C, $D, E$, platelet activating factor (PAF), dan prostaglandin (PGs) $E_{2}, F_{2}, D_{2}(4,13)$. Selain itu juga ovalbumin merangsang pelepasan sitokin (endothelins, cysteinyl leucotrienes (CysLTs), interleukin (IL)-13) dan growth factor (transforming growth factor (TGF)-, epidermal growth factor (EGF)) $(13,14)$. Growth factor akan secara langsung berperan dalam remodeling saluran nafas, yang salah satu manifestasinya adalah penebalan epitel saluran nafas dan penyempitan lumen bronkus.

Hiperplasia sel goblet yang terjadi pada remodeling saluran nafas juga turut berkontribusi secara signifikan terhadap penebalan lapisan epitel saluran nafas yang tersensitisasi (15). Peneliti lain juga menyebutkan bahwa kontribusi dari hiperplasia sel goblet ke penebalan epitel saluran nafas dapat terjadi oleh karena adanya efek penolakan dari mekanisme pengelupasan epitel, hal ini mungkin dapat diartikan sebagai terjadinya penebalan epitel saluran nafas (4). Fixman juga melaporkan bahwa ovalbumin dan adjuvant berupa aluminum hydroxide $(\mathrm{Al}(\mathrm{OH}) 3)$ menginduksi hiperreaktivitas bronkus sehingga terjadi hiperkontraksi otot polos yang menyebabkan bronkhokontriksi secara akut.

Secara statistik didapatkan ketebalan epitel bronkus yang semakin berkurang pada pemberian jinten hitam pada semua dosis jika dibandingkan kelompok kontrol positif . Penambahan jinten hitam pada semua kelompok perlakuan memberikan peningkatan ukuran keliling lumen bronkus jika dibandingkan dengan kelompok kontrol positif, dan yang menunjukkan perbedaan signifikan adalah pemberian jinten hitam dosis 4,8 $\mathrm{g} / \mathrm{kgBB}$.

Hambatan penebalan epitel bronkus mencit dan peningkatan ukuran keliling lumen bronkus tersebut 
menunjukkan dampak pemberian ekstrak jinten hitam yang diberikan bersamaan dengan sensitisasi allergen ovalbumin. Jinten hitam memiliki berbagai macam kandungan, diantaranya yang menonjol adalah thymoquinone dan nigellone. Thymoquinone telah dibuktikan memiliki efek antioksidan, antiinflamasi, antihistamin, dan analgesik (16). Thymoquinone, salah satu bahan aktif dalam ekstrak jintan hitam, dapat menginhibisi sitokin pro inflamasi, tromboksan B2 dan leukotrin B4 dengan mengalihkan jalur siklooksigenase dan 5-lipoksigenase dari metabolisme asam arakhidonat. (9). Kadar ovalbumin spesifik IgE, IgG serum. IL-4, IL-5 dan IL-13 cairan lavage bronkhoalveolar menurun pada kelompok yang diberikan thymoquinon. Efek anti inflamasi thymoquinone dapat menginhibisi growth factor. Hal ini akan menurunkan terjadinya hiperreaktivitas bronkus dan airway remodelling, yang salah satu manifestasinya adalah penebalan epitel saluran napas dan penyempitan lumen bronkus. Hiperplasia sel goblet, sebagai bagian dari remodeling saluran napas, juga akan mengalami hambatan.

Jinten hitam juga mempunyai efek relaksasi pada sediaan otot polos trakhea terpisah. Gilani melaporkan efek jinten hitam memiliki efek relaksasi otot polos dengan cara menghambat kanal kalsium pada otot polos. Jika influks

\section{DAFTAR PUSTAKA}

1. Noorcahyati S. Pemantauan Kadar Imunoglobulin $M$ (IgM) dan Imunoglobulin $G$ (IgG) Chlamydia pneumoniae pada Penderita Asma di Rumah Sakit Umum Pusat H. Adam Malik Medan. [Tesis]. Universitas Sumatera Utara, Medan. 2003.

2. Rahmawati I, Yunus F, dan Wiyono W. Patogenesis dan Patofisiologi Asthma. (Online ) 2003. http://www.kalbe.co.id/files/cdk/files/05 [diakses tanggal 24 November 2008].

3. Roni N. Tatalaksana Asma pada Anak. Prosiding The Recent Management of The Allergic Child Bagian IImu Kesehatan Anak FK UGM/ RSUP Dr. Sardjito Yogyakarta. Yogyakarta, 17 Juni 2000.

4. Tang ML, Wilson JW, Stewart AG, and Royce SG. Airway Remodelling in Asthma : Current Understanding and Implications for Future Therapies. Pharmacology \& Therapeutics. 2006; 112(2): 474-488.

5. Global Initiative for Asthma. Global Strategy for Asthma Management and Prevention. GINA Workshop Report. USA, January; 2002.

6. Barnes PJ and Adcock I. Transcriptation Factors and Asthma. European Respiratory Journal. 1998; 12(1): 221-234.

7. Ali BH and Bundlen G. Pharmacological and Toxicological Properties of Nigella sativa. Phytotherapy Research. 2003; 17(4): 299-305.

8. Riskawati dan Yhusi K. Efek Ekstrak Jinten Hitam (Nigella sativa) yang Ada di Indonesia terhadap Relaksasi Otot Polos Sediaan Trachea Terpisah Marmot (Cavia Porcellus). [Tugas Akhir]. Universitas Brawijaya, Malang. 2001.

9. Gazzar EM, Mezayen ER, Marecki JC, Nicolls MR, kalsium melewati kanal ini dihambat maka tidak terjadi kontraksi otot polos (17).

Pada mencit kelompok pemberian jinten hitam semua dosis, ketebalan epitelnya tidak berbeda signifikan dibanding kelompok kontrol negatif. Hal ini kemungkinan pada kelompok dosis $1,2 \mathrm{~g} / \mathrm{kgBB}$, dosis ekstrak jinten hitam sudah dapat menimbulkan efek pencegahan terhadap penebalan epitel bronkus model mencit asma. Selain itu karena interval dosis ekstrak jinten hitam yang terlalu sempit, sehingga belum dapat diketahui dosis toksik dari ekstrakjinten hitam.

Walaupun peningkatan ukuran lumen bronkus paling tinggi terdapat pada perlakuan kelompok dosis 4,8 $\mathrm{g} / \mathrm{kgBB}$, akan tetapi masih berbeda bermakna jika dibandingkan ukuran normal. Hal tersebut dimungkinkan karena adanya proses airway remodelling pada lumen bronkhus yang irreversibel.

Pemberian jinten hitam bisa mencegah penebalan epitel bronchus pada dosis optimal $2,4 \mathrm{~g} / \mathrm{KgBB} /$ hari dan meningkatkan ukuran keliling lumen bronchus pada dosis optimal $4,8 \mathrm{~g} / \mathrm{KgBB} /$ hari, meskipun belum mencapai ukuran normal.

Canastar A, and Dreskin SC. Anti-inflammatory Effect of Thymoquinone in a Mouse Model of Allergic Lung Inflammation. International Immunopharmacology. 2006; 6(7): 1135-1142.

10. Abbas AT, Abdel-Azis MM, Zalata KR, and Al-Galel TEA. Effect of Dexamethasone and Nigella sativa on Peripheral Blood Eosinophil Count, IgG1 and IgG2a, Cytokine Profiles and Lung Inflammation in Murine Model of Allergic Asthma. Egyptian Journal of Immunology. 2005; 12 (1): 95-102.

11. Hartati IB. Pengaruh Ekstrak Jinten Hitam (Nigella sativa) terhadap gambaran Histopatologi Trakea pada Tikus Wistar dengan Diet Atherogenik. [Tugas Akhir]. Universitas Brawijaya, Malang. 2001.

12. Leigh R, Ellies R, Wattie J, et al. Dysfunction and Remodeling of the Mouse Airway Persist after Resolution of Acute Allergen-induced Airway Inflammation. American Journal of Respiratory Cell and Molecular Biology. 2002; 27(5): 526-535.

13. Fadden ER. Harrison's Principles of Internal Medicine. 16th edition. USA: McGraw-Hill Companies. Inc.; 2005; p. 1508-1514.

14. Fixman ED, Stewart A, and Martin JG. Basic Mechanisms of Development of Airway Structural Changes in Asthma. European Respiratory Journal. 2007; 29(2):379-389

15. Temelkovski J, Hogan SP, Shepherd DP, Foster PS, and Kumar RK. An Improved Murine Model of Asthma: Selective Airway Inflammation, Epithelial Lesions and Increased Methacholine Responsiveness Following Chronic Exposure to Aerosolised Allergen. Thorax. 1998; 53(10): 849-856.

16. Randhawa M and Al-Ghamdi MA. A Review of The Pharmaco-therapeutics Effects of Nigella sativa. Pakistan Journal Medical Research. 2002;41(2):77-83 
17. Gilani AH, Jabeen $\mathrm{Q}$, and Khan MAU. A Review of Medicinal Uses and Pharmacological Activities of
Nigella sativa. Pakistan Journal of Biological Sciences. 2004; 7 (4): 441-451. 